\title{
Chemical Alterations of Hardwood Veneers Due to Thermal Treatment
}

\author{
Anete Meija-Feldmane \\ Visiting Research Asisstant \\ Latvia University of Life Sciences and \\ Technologies \\ Jelgava, Latvia \\ a.meija.feldmane@gmail.com
}

\author{
Andris Morozovs \\ Professor of the Department of Wood \\ Processing \\ Latvia University of Life Sciences and \\ Technologies \\ Jelgava, Latvia \\ andris.morozovs@1lu.1v
}

\author{
Uldis Spulle \\ Professor of the Department of Wood \\ Processing \\ Latvia University of Life Sciences and \\ Technologies \\ Jelgava, Latvia \\ uldis.spulle@1lu.lv
}

\begin{abstract}
Wood is the most popular building material in the world due to its universal versatility, although it has disadvantages - the difficulty to apply small diameter logs in construction, hygroscopicity and anisotropic swelling and shrinking. To solve these disadvantages, plywood from wood material is produced. Plywood is a material that can solve anisotropy, but it is still biodegradable by rot and stain fungi. Thermal treatment is a methodology that improves the durability of wood. In this paper aspen (Populus tremula L.), poplar (Populus $x$ canadensis Moench) and birch (Betula pendula Roth) were treated by steam (WTT) and vacuum (TERMOVUOTO) devices under $160^{\circ} \mathrm{C} / 50 \mathrm{~min}$ (birch and aspen), $204^{\circ} \mathrm{C} / 2 \mathrm{~h}, 214^{\circ} \mathrm{C} / 2 \mathrm{~h}, 217^{\circ} \mathrm{C} / 3 \mathrm{~h}, 218^{\circ} \mathrm{C} / 30$ min (birch and poplar). Chemical changes in treated veneers were investigated by ATR-FTIR (Attenuated Total Reflection Fourier Transform Infrared Spectroscopy) in a range $2000 \mathrm{~cm}^{-1}-800 \mathrm{~cm}^{-1}$. ATR-FTIR is a non-destructive methodology, which is important during manufacturing process quality control. Untreated poplar wood and aspen wood had similar ATR-FTIR spectra because both species belong to Populus genus. Untreated birch wood had higher absorption intensity peak at $1740 \mathrm{~cm}^{-1}$, which indicates the $\mathrm{C}=\mathrm{O}$ bond stretching in the carboxyl group depicting more acetyl groups in birch wood than in aspen/ poplar. According to spectral data, birch wood, treated in TERMOVUOTO process at $200^{\circ} \mathrm{C}$ for 2 hours is chemically almost identical to untreated one. WTT process causes the most significant changes in the chemistry of both in aspen and birch. Therefore, regime $160^{\circ} \mathrm{C} / 50 \mathrm{~min}$ in water vapour is more aggressive than treatments at higher temperatures and under reduced pressure. It is expected that plywood produced from WTT treated veneers will have reduced strength in comparison with TERMOVUOTO process produced ones.
\end{abstract}

Keywords - FTIR, termovuoto, veneers, WTT.

\section{INTRODUCTION}

Wood is used extensively all around the globe since the beginning of civilization. Throughout history, men have discovered the advantages and disadvantages of the material. Wood has excellent strength to weight ratio [1], it is visually appealing and easy to handle. There are big differences among the wood species because of its density, hardness and durability peculiarities that should be taken into consideration for the chosen usage.
Several wood drawbacks are characteristic to all species - wood is a hygroscopic material with anisotropic properties depending on grain direction. Hygroscopicity leads to its sensitivity towards fungal attacks [1]. Rot and stain fungi are the two main groups, that threaten wood. Hemicelluloses are the main wood ingredient that is nutrient for fungi.

From the construction point of view, it is burdensome to use logs with a small diameter, therefore they are rotarycut veneers and from them engineered wood - plywood is made. Plywood is a material that can solve the usage of small diameter logs. It has dimensional stability [2] and reduced anisotropy, but it still remains biodegradable.

Thermal treatment is a methodology that improves the durability of wood. Thermal modification occurs at elevated temperatures in the reduced oxygen environment. There are many thermal treatment methodologies available. Thermowood $\AA$, Plato $\operatorname{wood} \AA$ and Rectified $\operatorname{wood} \AA$ are commercial examples, but there are also the non-commercial methodologies as WTT (Wood Treatment Technology). Hemicelluloses are the wood constituent that is degraded the most during thermal treatment. The changes occur in lignin are mainly by self-condensation, but cellulose is the most rigid component of wood during thermal treatment [3]. Wood degradation is catalysed due to acetyl group cleavage from hemicelluloses and acetic acid formation. Wood thermal treatment with simultaneous removal of destruction products reduces the degree of degradation. Silvapro ${ }^{\circledR}$ [4], SmartHeat ${ }^{\circledR}$ [5] and Termovuoto ${ }^{\circledR}[6]$ are the processes that use the reduced pressure for that.

Chemical changes in veneers due to thermal modification can be investigated by ATR-FTIR (Attenuated Total Reflection Fourier Transform Infrared Spectroscopy), which is a non-destructive methodology. This technique is based on the determination of the interaction between an IR (infrared) radiation and a sample. It measures the frequencies at which the sample absorbs (wavelength) and the intensities of these absorptions. Functional groups are responsible for the absorption of radiation at different frequencies, therefore this information can be used for identification of samples

Print ISSN 1691-5402

Online ISSN 2256-070X

http://dx.doi.org/10.17770/etr2019vol1.4147

(C) 2019 Anete Meija-Feldmane, Andris Morozovs, Uldis Spulle. Published by Rezekne Academy of Technologies.

This is an open access article under the Creative Commons Attribution 4.0 International License. 
chemical structure [7]. FTIR can be used also in quality control during manufacturing of thermally modified wood. The main peaks that characterize chemical changes during thermal modification are unconjugated $\mathrm{C}=\mathrm{O}$ stretching at $1724-1734 \mathrm{~cm}-1$ that corresponds to esters, ketones, aldehydes and acids [8]. and $\mathrm{C}=\mathrm{C}$ benzene ring vibration in lignin 1504-1516 cm-1 [9], [10] as well as $\mathrm{C}-\mathrm{H}$ deformation in cellulose at $892 \mathrm{~cm}-1$ [10].

The aim of this study is to evaluate chemical changes in hardwood veneers after thermal modification by means of FTIR.

\section{MATERIALS AND METHODS}

Three low-density hardwood species were used aspen (Populus tremula L.), poplar (Populus $x$ canadensis Moench) and birch (Betula pendula Roth). Rotary cut aspen and birch veneers were treated with WTT technology under the previously determined optimal regime $160^{\circ} \mathrm{C} / 50 \mathrm{~min}$. The process is described in detail previously in Grinins paper [11]. Rotary-cut poplar and birch veneers $600 \times 600 \times 1.5 \mathrm{~mm}$ were treated in four experimental regimes $204^{\circ} \mathrm{C} / 2 \mathrm{~h}, 214^{\circ} \mathrm{C} / 2 \mathrm{~h}, 217^{\circ} \mathrm{C} / 3$ $\mathrm{h}, 218^{\circ} \mathrm{C} / 30 \mathrm{~min}$ in TERMOVUOTO process, which is in more detail described by Sandak [12], although this process was modified - veneers were treated under convective heat regime, between aluminium plates in packs 3 to 12 pieces, which is more alike processes in manufacturing.

Sample size used for obtaining spectra were $20 \times 20 \times$ thickness $\mathrm{mm}$; without veneer surface treatment.

ATR - FTIR spectra were obtained using BRUKKER Alpha device with the platinum-diamond prism. Mathematical processing of spectra was made using OPUS 7.5 software. The spectra were taken in a range 2000 to $800 \mathrm{~cm}^{-1}$ with spectral resolution $4 \mathrm{~cm}^{-1}$, using 72 repeated scans of each spectrum. Afterwards, the spectra were normalized, using cellulose $\mathrm{CH}$ vibration peak at $1030 \mathrm{~cm}^{-1}$ as a reference and the baseline was corrected using 62 points and 10 iterations, the influence of $\mathrm{CO}_{2}$ were excluded. Integration of peak area was made according to R-method built-in OPUS software.

Spectra that characterizes certain treatment regime were obtained by averaging spectra from three samples, measured in three different places of each sample (nine spectra in total).

Spectral results at which absorbance occurs are presented by putting wavelength $\left(\mathrm{cm}^{-1}\right)$ on the $\mathrm{x}$-axis and absorbance (relative amount of infrared radiation absorbed by sample) on the y-axis.

\section{RESULTS AND DISCUSSION}

When comparing untreated aspen, poplar and birch spectra, it can be concluded that untreated birch samples have significantly higher absorbance at $1734 \mathrm{~cm}^{-1}$, which reveals the $\mathrm{C}=\mathrm{O}$ stretching in the non-conjugated carbonyl group [13] depicting initially more acetyl groups in birch wood than in aspen/poplar that coincides with Kocaefe [14]the wood is heated to higher temperatures than those of conventional drying. The wood structure changes due to decomposition of hemicelluloses, ramification of lignin, and crystallization of cellulose. The wood becomes less hygroscopic. These changes improve the dimensional stability of wood, increase its resistance to microorganisms, darken its color, and modify its hardness. However, wood also might loose some of its elasticity. Consequently, the heat treatment conditions have to be optimized. Therefore, it is important to understand the transformation of the chemical structure of wood caused by the treatment. In this study, the modification of the surface composition of the wood was followed with Fourier transform infrared spectroscopy (FTIR. It indicates that birchwood contains more hemicelluloses with acetylated side groups than aspen or poplar woods. Minor differences between aspen and poplar wood can be observed at $1150 \mathrm{~cm}^{-1}$ and $1100 \mathrm{~cm}^{-1}$, which implies minor differences in the content of cellulose in these veneers [8].

The main thirteen peaks that can be seen in ATR-FTIR spectra of veneers in the wavelength range $2000 \mathrm{~cm}^{-1}$ $800 \mathrm{~cm}^{-1}$ are listed in Table I.

TABLE I.

\begin{tabular}{|c|c|c|c|}
\hline \multirow{2}{*}{$\begin{array}{l}\text { FTIR } \\
\text { peaks }\end{array}$} & \multicolumn{3}{|c|}{ Characterization } \\
\hline & Chemical Group & Constituent & Source \\
\hline $\begin{array}{l}895- \\
903\end{array}$ & $\begin{array}{l}\mathrm{C}_{1}-\mathrm{H} \text { bending of anomeric car- } \\
\text { bon }\end{array}$ & xylan & {$[13]$} \\
\hline $\begin{array}{l}1026- \\
1032\end{array}$ & $\begin{array}{l}\mathrm{C}-\mathrm{O}-\mathrm{C} \text { stretching of aliphatic } \\
\text { ether bond }\end{array}$ & $\begin{array}{l}\text { xylan, } \\
\text { lignin }\end{array}$ & [13] \\
\hline $\begin{array}{l}1048- \\
1051\end{array}$ & $\begin{array}{l}\text { C-O stretching primary alco- } \\
\text { hol, arabinoxylans }\end{array}$ & $\begin{array}{l}\text { hemicellu- } \\
\text { loses }\end{array}$ & $\begin{array}{l}{[15],} \\
{[16]}\end{array}$ \\
\hline $\begin{array}{l}1108- \\
1110\end{array}$ & $\begin{array}{l}\text { C-O stretching secondary al- } \\
\text { cohol }\end{array}$ & cellulose & {$[15]$} \\
\hline $\begin{array}{l}1159- \\
1166\end{array}$ & $\begin{array}{l}\mathrm{C}-\mathrm{O}-\mathrm{C} \text { symmetrical vibration } \\
\mathrm{C}=\mathrm{O} \text { in conjugated ester } \\
\text { groups (lignin) }\end{array}$ & $\begin{array}{l}\text { cellulose, } \\
\text { hemicellu- } \\
\text { lose, lignin }\end{array}$ & $\begin{array}{l}{[17]} \\
{[18]}\end{array}$ \\
\hline $\begin{array}{l}1231- \\
1235\end{array}$ & $\begin{array}{l}\text { CO-OR stretching of acyl-ox- } \\
\text { ygen bond (hemicellulose) } \\
\text { Stretching of the benzene-ox- } \\
\text { ygen bond (lignin) } \\
\text { O-H phenolic }\end{array}$ & $\begin{array}{l}\text { hemicellu- } \\
\text { lose, lignin }\end{array}$ & $\begin{array}{l}{[13]} \\
{[19]}\end{array}$ \\
\hline $\begin{array}{l}1317- \\
1322\end{array}$ & $\begin{array}{l}\mathrm{C}-\mathrm{O} \text { in carboxylic acids, alco- } \\
\text { hols, esters in hemicellulose } \\
\mathrm{C}-\mathrm{H} \text { vibrations in cellulose }\end{array}$ & $\begin{array}{l}\text { hemicel- } \\
\text { luloses, } \\
\text { cellulose }\end{array}$ & $\begin{array}{l}{[20],} \\
{[21]}\end{array}$ \\
\hline $\begin{array}{l}1369- \\
1375\end{array}$ & C-H bending & $\begin{array}{l}\text { cellulose, } \\
\text { hemicellu- } \\
\text { lose }\end{array}$ & $\begin{array}{l}{[13]} \\
{[19]}\end{array}$ \\
\hline $\begin{array}{l}1416- \\
1422\end{array}$ & $\begin{array}{l}\text { C-H Stretching of an aromatic } \\
\text { skeleton bending }\end{array}$ & $\begin{array}{l}\text { lignin, } \\
\text { cellulose }\end{array}$ & {$[13]$} \\
\hline $\begin{array}{l}1447- \\
1463\end{array}$ & $\begin{array}{l}-\mathrm{CH}_{3} \text { and }-\mathrm{CH}_{2} \text { unsymmetrical } \\
\text { bending } \\
\text { Aliphatic } \mathrm{C}-\mathrm{H} \text { bendings }\end{array}$ & $\begin{array}{l}\text { lignin, } \\
\text { cellulose }\end{array}$ & $\begin{array}{l}{[13]} \\
{[22]} \\
{[19]}\end{array}$ \\
\hline $\begin{array}{l}1506- \\
1512\end{array}$ & $\begin{array}{l}\mathrm{C}=\mathrm{C} \text { Stretching of aromatic } \\
\text { skeleton }\end{array}$ & lignin & $\begin{array}{l}{[13],} \\
{[19]}\end{array}$ \\
\hline $\begin{array}{l}1590- \\
1597\end{array}$ & $\begin{array}{l}\mathrm{C}=\mathrm{C} \text { Stretching of the aromat- } \\
\text { ic skeleton; } \mathrm{C}\end{array}$ & lignin & {$[13]$} \\
\hline $\begin{array}{l}1732- \\
1740\end{array}$ & $\begin{array}{l}\mathrm{C}=\mathrm{O} \text { stretching of non-conju- } \\
\text { gated carbonyl } \\
\text { Uronic acid and acety lgroups } \\
\text { in hemicelluloses }\end{array}$ & $\begin{array}{l}\text { xylan, } \\
\text { hemicellu- } \\
\text { loses }\end{array}$ & $\begin{array}{l}{[13]} \\
{[22]}\end{array}$ \\
\hline
\end{tabular}


The extent of thermal alteration depends on several factors such as the state of the wood specimens, the temperature load and the duration of the treatment [23]. The intensity of the IR radiation absorption peak at 898 $\mathrm{cm}^{-1}$ is the lowest for untreated specimens 0.07 but it increases till 0.11 for the veneers treated at the highest treatment temperature. This band is present in the wood spectra due to the $\beta$-pyranose ring but it is absent in the spectra of lignin, so it characterizes wood cellulosic structures [22]. The peaks around $1030 \mathrm{~cm}^{-1}$ have minor alterations by thermal treatment so the cellulose $\mathrm{C}-\mathrm{H}$ bond vibration peak at $1030 \mathrm{~cm}^{-1}$ was used as a reference in the normalization of spectra.

Aspen wood was treated according to WTT technology only. The moist environment in the WTT chamber favoured degradation of hemicelluloses with carbonyl compounds formation during aspen wood thermal treatment that caused the increased absorption at $1730 \mathrm{~cm}^{-1}$ in comparison with the untreated aspen wood samples spectra in Fig. 1. It coincides with the modified samples lowered absorption at $1240 \mathrm{~cm}^{-1}$ in Fig. 1. This absorption band is characteristic for acyl-oxygen bond stretching in hemicelluloses esters $\mathrm{H}_{3} \mathrm{CCO}-\mathrm{OR}$. It implies to deacetylation of hemicelluloses during thermal modification. The increased absorption of treated samples at $1100 \mathrm{~cm}^{-1}$ and $1050 \mathrm{~cm}^{-1}$ implies that the content of destruction products has increased significantly.

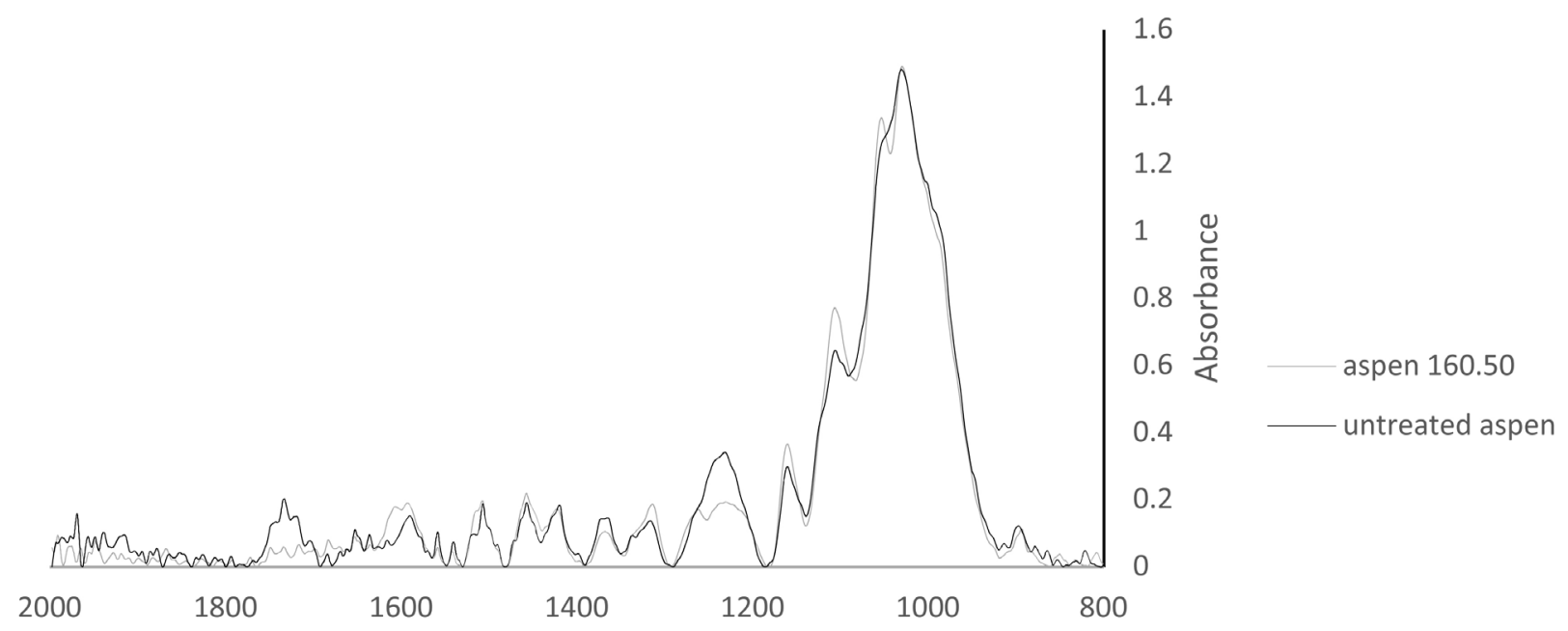

Fig. 1 ATR-FTIR spectra of aspen

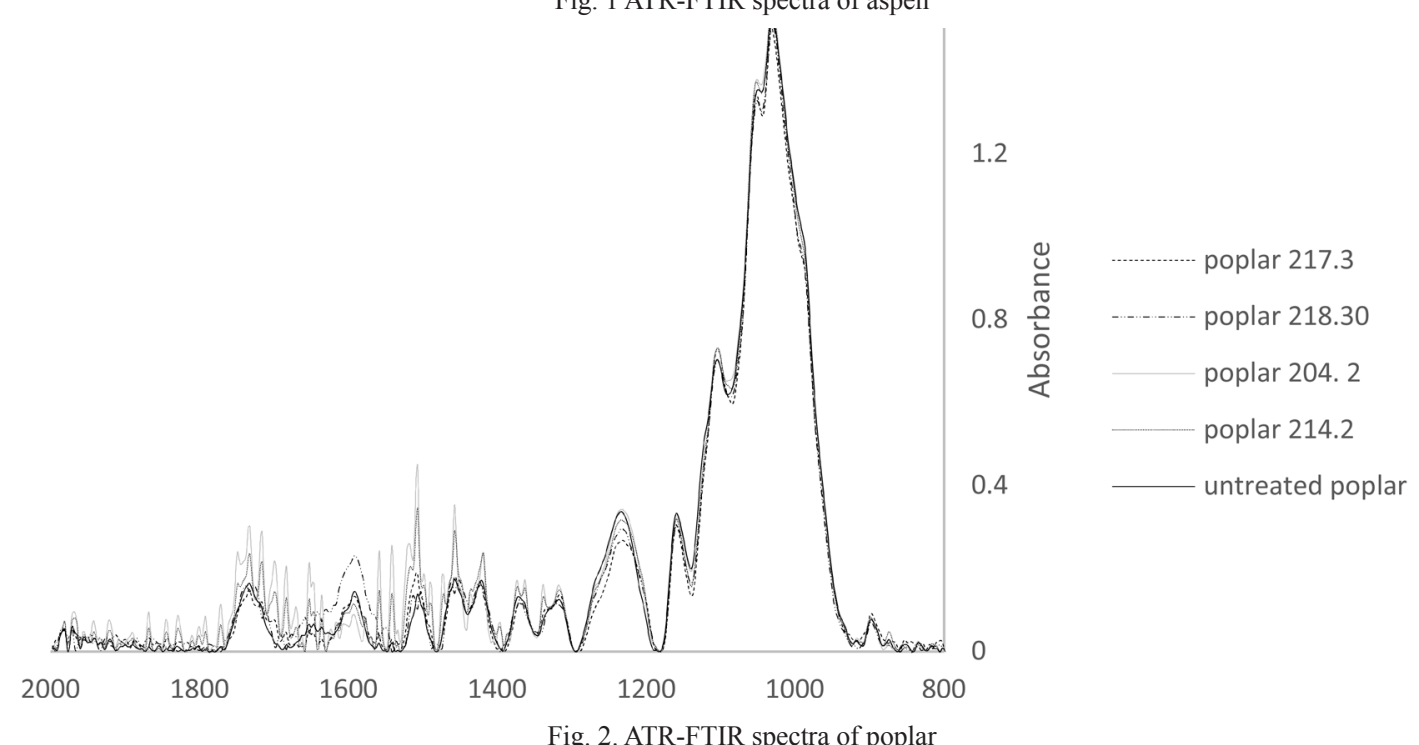

During wood thermal modification according to TERMOVUOTO process, wood components gasiform destruction products and water vapour were evacuated from modification environment that decreased their hydrolytic and acid catalysis effect on wood in comparison with WTT technology. The increase of severity of TERMOVOUTO process $\left(204^{\circ} \mathrm{C} / 2 \mathrm{~h}, 214^{\circ} \mathrm{C} / 2 \mathrm{~h}, 217^{\circ} \mathrm{C} / 3\right.$ $\mathrm{h}, 218^{\circ} \mathrm{C} / 30 \mathrm{~min}$ ) decreased and slightly shifts to right the absorption band peak at $1230 \mathrm{~cm}^{-1}$ of ATR-FTIR spectra of modified poplar wood samples as shown in Fig. 2.

This could characterize cleavage in hemicellulose structure. Disturbance in spectra can be explained with surface roughness, due to larger brittleness of thermally treated poplar wood compared to birch wood. 


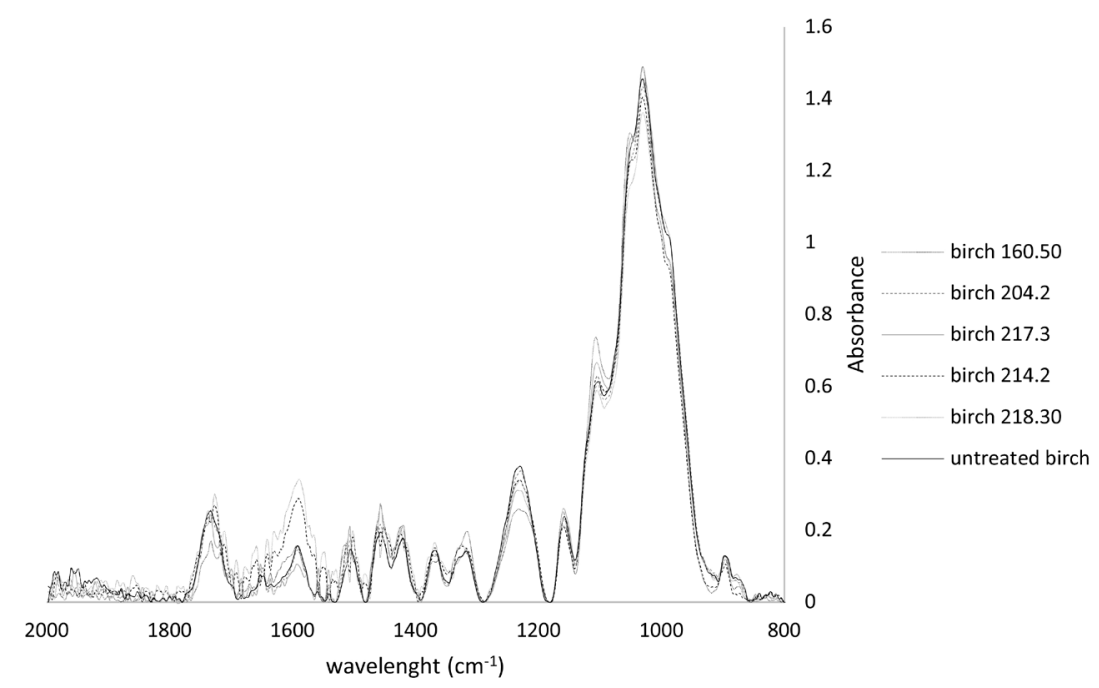

Fig. 3 ATR-FTIR spectra of birch

Birch is the only species of wood in this research that was treated both in WTT and THERMOVOUTO technology. In Fig. 3 there can be seen that alterations in birch wood spectra are the largest at $1580-1588 \mathrm{~cm}^{-1}$ highest for birch wood samples treated with $218^{\circ} \mathrm{C} / 30 \mathrm{~min}$, with a gradual reduction for $214^{\circ} \mathrm{C} / 2 \mathrm{~h}$ then $160^{\circ} \mathrm{C} / 50 \mathrm{~min}$, then $217^{\circ} \mathrm{C} / 3 \mathrm{~h}$ and $204^{\circ} \mathrm{C} / 2 \mathrm{~h}$. This peak characterizes lignin aromatic ring vibration in aromatic $\mathrm{C}=\mathrm{C}$ band and this coincides with findings of Ercin [22], where this peak increases with increasing treatment temperature and the relative content of lignin in material increased due to hemicelluloses decomposition. As lignin holds the wood cells together, alteration of its structure can weaken the material. At $1100 \mathrm{~cm}^{-1}$ the height of peak increases only for $160^{\circ} \mathrm{C} / 50 \mathrm{~min}$ regime, which means that alcohols are formed as decomposition products from cellulose.

\section{CONClusions}

Treatment regime $204^{\circ} \mathrm{C} / 2 \mathrm{~h}$ displays very small changes in the ATR-FTIR spectra. Overall, when compared to birch, aspen and poplar display sizable chemical changes in the wood structure. The peak of hemicelluloses at $1740 \mathrm{~cm}^{-1}$ and the peak of lignin at $1590 \mathrm{~cm}^{-1}$ characterize the severity of the treatment parameters. WTT process causes the most significant changes both in aspen and birch wood. So, regime $160^{\circ} \mathrm{C} / 50 \mathrm{~min}$ in water vapour is more aggressive than treatments with higher temperatures, but under reduced pressure. To obtain a comprehensive picture about changes in veneers due to thermal treatment, apart from ATR-FTIR spectra subsidiary methods should be used.

Plywood produced from veneers thermally treated according to WTT technology is expected to have less strength than from TERMOVUOTO process produced ones, due to more intense degradation of wood polymer structure.

\section{ACKNOWLEDGEMENTS}

The research was carried out within the project P5 "Plywood with improved durability" co-financed by Implementation of Research Program at Latvia University of Life Sciences and Technologies.

\section{REFERENCES}

[1] C.A.S. Hill, "Thermal Modification of Wood," in Wood modification - Chemical, Thermal and Other Processes, John Wiley\&Sons, 2006, pp. 99-127.

[2] A. Lovrić, V. Zdravković, R. Popadić, and G. Milić, "Properties of Plywood Boards Composed of Thermally Modified and Nonmodified Poplar Veneer," BioResources, vol. 12 (4), pp. 85818594, 2017.

[3] B. F. Tjeerdsma and H. Militz, "Chemical changes in hydrothermal treated wood: FTIR analysis of combined hydrothermal and dry heat-treated wood," Holz als Roh - und Werkst., vol. 63 (2), pp. 102-111, 2005

[4] G. Rep, F. Pohleven, and S. Košmerl, Development of Industrial Kiln for Thermal Wood Modification by a Procedure with Initial Vacuum and Commercialisation of Modified Silvapro ${ }^{\circledR}$ Wood. European Conference on Wood Modification, September 17-18, 2012, Ljubjana, Slovenia, pp 13-20.

[5] J. Van Acker, S. Michon, J. Van Den Bulcke, and I. De Windt, "Limited variability in biological durability of thermally modified timber using vacuum based technology," International Research Group of Wood Preservation, p. IRG/WP 11-40567, 2011.

[6] S. Ferrari, I. Cuccui, and O. Allegretti, "Thermo-vacuum Modification of some European Softwood and Hardwood Species Treated at Different Conditions," BioResources, vol. 8 (1), pp. 1100-1109, Jan. 2013.

[7] C. M. Simonescu, Application of FTIR Spetroscopy in Environmental Studies in Advanced Aspects of Spectroscopy. InTech, 2012.

[8] R. Herrera, X. Erdocia, R. Llano-Ponte, and J. Labidi, "Characterization of hydrothermally treated wood in relation to changes on its chemical composition and physical properties," Journal of Analytic and Applied Pyrolysis, vol. 107, pp. 256-266, May 2014

. [9] K. Srinivas and K. K. Pandey, "Photodegradation of thermally modified wood," Journal of Photochemistry and Photobiology B: Biology, vol. 117, pp. 140-145, 2012.

[10]A. Tarmian and A. Mastouri, "Changes in moisture exclusion efficiency and crystallinity of thermally modified wood with aging," iForest - Biogeosciences and Forestry, vol. 12 (1), pp. 92 97, 2019.

[11] J. Grinins et al., "Thermo-hydro treated (THT) birch veneers for producing plywood with improved properties," Holzforschung, vol. 70 (8), Jan. 2016.

[12] A. Sandak et al., Thermal modification of poplar veneers in vacuum conditions,"European Conference on Wood Modification, October 26-28, 2015, Helsinki, Finland

[13] Y. Liu et al., "Wood Veneer Dyeing Enhancement by Ultrasonic-assisted Treatment," BioResources, vol. 10 (1), pp. 1198-1212, Jan. 2015.

[14]D. Kocaefe, S. Poncsak, and Y. Boluk, "Effect of thermal treatment on the chemical composition and mechanical properties of birch and aspen," BioResources, vol. 3 (2), pp. 517-537, Apr. 2008. 
[15] J. Coates, "Interpretation of Infrared Spectra, A Practical Approach," Encyclopedia of Analytical Chemistry, pp. 1081510837, 2000.

[16] M. Kacuráková, "FT-IR study of plant cell wall model compounds: pectic polysaccharides and hemicelluloses," Carbohydrate Polymers, vol. 43 (2), pp. 195-203, Oct. 2000.

[17]B. S. Gupta, B. P. Jelle, and P. Rüther, FTIR Spectroscopy as a Tool to Predict Service Life of Wooden Cladding. CIB World Congress 2010 - Building a Better World, May 10-13, 2010, Salford, United Kingdom.

[18] O. Faix, Fourier Transform Infrared Spectroscopy, Springer, Berlin, Heidelberg, 1992, pp. 233-241.

[19]R. Bodirlau and C. A. Teaca, "Fourier transform infrared spectroscopy and thermal analysis of lignocellulose fillers treated with organic anhydrides," Romanian Reports in Physics, vol. 54 (1-2), pp. 93-104, 2009.
[20] A. Attia, R. Aboelenin, S. Kheder, G. Mohmed, and S. El-Shafey, "The Effect of Activation Method on the Adsorption Performance of Saw-Dust Activated Carbon," British Journal of Applied Science and Technology vol. 7(3), pp. 302-315, Jan. 2015.

[21]M. Veizović, A. Straže, N. Todorović, K. Čufar, M. Merela, and G. Milić, Characterization of subfossil oak wood from central Serbia using SEM and FTIR spectroscopy, Conference Living with modified wood, December 12-13, 2018, Belgrade, Serbia

[22] D. Erçin and Y. Yürüm, "Carbonisation of fir (Abies bornmulleriana) wood in an open pyrolysis system at 50-300 ${ }^{\circ} \mathrm{C}$," Journal of. Analytic and Applied Pyrolysis, vol. 67 (1), pp. 11-22, 2003.

[23]E. Windeisen and G. Wegener, "Behaviour of lignin during thermal treatments of wood," Industrial. Crops and Products vol. 27 (2), pp. 157-162, 2008. 